\title{
Social Enterpreneurship and Its Contribution to Rural Development: A Study of Shimoga District
}

\author{
Eswar kumar belli $\mathrm{S}^{1}$, Dr.T.S Raghvendra ${ }^{2}$ \\ Research Scholar, Department of Economics, L.B and SBS College (Autonomous) Sagar,Kuvempu University- \\ 577401, Karnataka, India. \\ Associate Professor,Department of Economics, L.B and SBS College (Autonomous) Sagar,Kuvempu University- \\ 577401 Karnataka, India.
}

\begin{abstract}
Sri Kshetra Dhrmasthala Rural Development Project (SKDRDP) launched in the year 1982 by Dr. D. Veerendra Heggade, Dharmadhikari of Dharmasthala, a small temple town in South India aims towards the upliftment of rural poor. SKDRDP is active at present in the State of Karnataka in South India where it is engaged in intensive fight against poverty, ignorance, illiteracy, alcoholic abuse, gender discrimination, division of villages on the lines of caste, creed and money power. SKDRDP has promoted various income generation activities in production and service sector. Self help groups are motivated, trained and assisted in setting up group ventures to help rural poor women with their own income escape poverty permanently through self employment or entrepreneurship. SKDRDP is the focus of this research paper due to Social Entrepreneurship and Its contribution in Rural Development, its central role in development promotion among rural poor. It is under this programme many people earn their livelihood from group ventures. Many women support themselves and their families through the income they earn from their Social Entrepreneurship activities of SKDRDP. In this research paper the author have made an attempt to understand the key support structure and identify the success factors for creating, developing and sustaining.
\end{abstract}

Keywords: Activities of SKDRD, Rural Development, Social Entrepreneurship,

\section{Introduction:}

India has the world's second largest labour force of 516.3 million people and although hourly wage rates in India have more than doubled over the past decade, the latest World Bank report states that approximately 350 million people in India currently live below the poverty line. With an estimated population of 1.2 billion people, this means that every third Indian is bereft of even basic necessities like nutrition, education and health care and many are still blighted by unemployment and illiteracy. Social entrepreneurs can help alleviate these issues by putting those less fortunate on a path towards a worthwhile life. Rather than leaving societal needs to the government or business sectors, they can solve the problem by changing the system. In this context the present study makes an attempt to overview the contributions of SKDRDP, promoted by Dr. D. Veerendra Heggade, Dharmadhikari, a renowned social entrepreneur to the marginalized sections of the society. This paper will cover the contributions of various programmes like Pragathi Bhandhu, Jnana Vikasa, Agriculture Extension, Pragathivana, Swagruha, Pragathinidhi, Gramakalyana, Jnanadeepa, Siri, Janajagruthi, etc.

In the year 2006 Nobel Prize was awarded to Prof. Mohammad Younis and Grameen Bank for the excellent efforts in the field of promoting economic and social Development in the poorest sections of the society. Thereafter the concept of social entrepreneurship gained importance 2 throughout the world. Many NGOs, profit sector and foundations started to represent as social enterprises.

Rural development is based on sustainable development with available resources. The main aim of rural development schemes is to generate employment opportunities, alleviate poverty by harnessing the available resources. The Government of India has implemented many schemes for the self-employment of the rural poor. SHG activities are initially confined to internal savings and internal lending, borrowing for consumption purpose. Later on emphasis shifted from consumption credit to investment. At present SHGs are considered as an effective participatory process in development endeavors. SHGs are slowly entering into IGAs, as a measure of poverty alleviation or enhancing income levels as well as quality of life of the rural mass. Initially NGOs have encouraged the members of SHGs to take up individual enterprises and were induced to avail various Government schemes. Most of the SHG members who have a very low economic profile are confronted with a number of hurdles. As the SHG concept has imbibed and developed group consciousness, it was realized that group enterprise is a possible measure to encourage income-generating activities among the members, of the SHGs. 


\section{Social Enterpreneurship And Skdrdp}

Dr. D .Veerendra Heggade, Dharmadhikari, Shri Kshetra Dharmasthala., had recognised the social problems and thought of bringing change in the society through various supportive interventions. Employment generation, economic and social empowerment of the weaker and downtrodden sections of the society are the main concern. In order to materialise his dream of solving socio economic problems of the poor, he founded Shri Kshetra Dharmasthala Rural Development Project (SKDRDP) in the year 1982, it is a pioneering NGO in Shimoga district of Karnataka State 4 is actively associated with the implementation of SGSY in the district. Under the SGSY, higher degrees of incentives are offered for group enterprises. The main beneficiaries of SGSY are the people below the poverty line and members of SHGs. After a careful analysis of the project and the identification of beneficiaries, the Agency - Government / NGO - imparts necessary training to empower the people below the poverty line to take up IGAs either individually or in group. Ever since, the project has encompassed various aspects of rural development to make the rural living an enjoyable process. SKDRDP is active at present in the state of Karnataka and more intensely in west coast where it is engaged in intensive fight against poverty, ignorance, illiteracy, alcoholic abuse, and gender discrimination, division of villages on the lines of caste, creed and money power. The various programmes introduced by SKDRDP since 1982 .

1. Pragathi Bhandhu : association of small and marginal farmers

2. Jnana Vikasa : Women Empowerment Programmes

3. Agriculture Extension : training and support for agriculture

4. Rain water harvesting :irrigation and water shed programmes

5. Pragathivana : environmental protection and aforestation

6. Swagruha : Housing, Alternative sources of energy , rural sanitation programmes

7. Pragathinidhi : Microfinance programmes

8. Sampoorna Suraksha : health Insurance

9. Gramakalyana: community development, creation of rural infrastructure

10. Jnanadeepa : primary education programmes

11. Hindu Rudrabhumi: crematorium development project

12. Siri : income generation activities for groups

13. Janajagruthi : Deaddiction camps.

\subsection{Achievements during 2012-13:}

* SKDRDP presently consist of 2,13,788 self help groups consists of 23,24,823 clients

* Groups promoted by SKDRDP have made total turnover of Rs.2593.00 crores

* SHGs promoted under SIRI achieved a turnover of 7.66 crores

* Sujnananidhi scholarship scheme launched by SKDRDP helped 10,491 students with total Amount of 11.03 crores

* Community development programme of SKDRDP provided teachers to 450 Schools

* Actively participated in the flood relief programme in north Karnataka.

\section{A brief profile of the four major schemes of SKDRDP SIRI- Group enterprises}

The SKDRDP has promoting economic empowerment among the poor landless families by introducing various income generation activities both in production and service sector. Self help groups are motivated, trained and assisted in setting up various group ventures. These groups are given professional assistance in acquiring the skills, finance, raw materials procurement, production and marketing of the products. A brand name "SIRI" has been created to market the products produced by the groups include, fast moving chemical products like detergent cake, detergent powder, phenyls, washing liquids, scouring powder, candles, incense sticks etc., confectioneries sweets and condiments, packed foods, pickles, readymade garments, etc., are being manufactured and sold under the brand name "SIRI".

\subsection{PRAGATHINIDHI}

Microfinance (MF) is one of the key areas which SKDRDP is handling since 1992 and has gained expertise in MF over the years. The stakeholders' financial needs for livelihood promotion, consumption, productive agriculture and to develop infrastructures such as house, toilet, electricity, gobargas etc. are met with the funds provided by microfinance. The funds required for lending are sourced through the savings of the members which is deposited with the group's account. Another source of funds is bank loans. The funds provided under the programme are called as 'pragathinidhi'. The members availing Pragathi Nidhi pay back in weekly installments. SKDRDP today is the biggest NGO MFI in the country. 'Pragathinidhi' has so far funded up to Rs. 2,338.69 crores. 50,584 groups were added this year to the existing 85,826 groups. The loans were given to 
more than $1,36,400$ groups and the recovery rate was $100 \%$. During the year 2010-11, Pragathinidhi saw a leap in its activity amounting to Rs. 779.18 crores in comparison to the previous year's Rs.1,310.11 crores.

No. of loans availed by the members for various purposes under micro-credit:

- Agricultural Development Program 7,06,224

- Irrigation Programs $1,80,210$

- Housing and Sanitations 9,63,839

- $\quad$ Self Employment 5,55,022

- Other programs $25,20,388$

\subsection{PRAGATHI BHANDHU GROUPS:}

In this model, five to eight small and marginal farmers come together to form a group and undertake labour sharing once in a week. They also make small savings per week and take up financial transactions. They draw a five year plan defining the financial Investments to be made for development over the years. This helps them to set up goals and try to achieve them. Another feature of the Pragathi bhandhu SHG is the mixed cropping practiced by the members of the group. This helps them to get steady income on a daily basis which helps them to meet their weekly loan repayment obligations. The members borrow money for their farming activities to be repaid over weeks from their multiple farming produces and farm labour work done by these farmers in the neighborhood large farmer. In the year 2012-13, the total man days worked 4.89 crores. The value of labour comes to Rs 733 crores (per day per person Rs 150)

\subsection{JNANAVIKASA WOMEN SHG:}

The women in rural areas have little opportunity to express their talents, views and skills in any forum. They are tied up with their household duties taking care of family. Jnana Vikasa is a forum for women to develop their skills expresses their innate talents andempower themselves in the company of the fellow rural community. The Jnana Vikasa is also self help groups but with a difference in that these groups meet once in week for financial affairs and once in a month they undertake capacity building programs, awareness programs for about two hours in a common centre. The issues discussed during the meeting are related to the way of living and improving the livelihood and living environs. During the year 2012-13, 2, 16,508 Jnanavikasa Kendras have been active in 20,000 villages, 24,46,966 Families involved and total savings mobilized Rs58,240lakhs.

\subsection{MICRO INSURANCE PROGRAMME:}

SKDRDP has introduced insurance products to protect the stakeholders against hospitalization, death, permanent disability, maternity expenses, calamities etc. the scheme is named as Sampoorna Suraksha. The local hospitals are engaged as network hospitals to provide cash free treatment to the policy holders. During the year 2012-13. 10, 89,525 members enrolled for sampoorna suraksha programme. Sofar a record no. of 55,331 members has received benefit to the extent of Rs. 31.56 corers under the scheme during the year. The total claims settled since inception of the scheme surpassed 214.31 corers.

\section{Skdrdp And Sgsy:}

SKDRDP is the leading NGO in implementing the SGSY scheme of government of India in Shimoga district of Karnataka state. The role of SGSY in the socio economic transformation of the SHG members is discussed here. However the researcher has confined himself to the demographic profile comprising the age, education, occupation, and socio economic variables of income and savings, economic activity, expenditure pattern of the members.

Table: 1 Age profile of the SHG members who availed SKDRDP benefits:

\begin{tabular}{|c|c|c|c|c|}
\hline \multirow{2}{*}{ Age } & \multicolumn{2}{|c|}{ Shimoga } & \multicolumn{2}{c|}{ Bhadravathi } \\
\cline { 2 - 5 } & No & $\%$ & No & $\%$ \\
\hline $20-29$ & 13 & 52 & 12 & 48 \\
\hline $30-49$ & 7 & 28 & 9 & 36 \\
\hline $50-59$ & 4 & 16 & 3 & 12 \\
\hline 60 and above & 1 & 4 & 1 & 4 \\
\hline Total & $\mathbf{2 5}$ & $\mathbf{1 0 0}$ & $\mathbf{2 5}$ & $\mathbf{1 0 0}$ \\
\hline
\end{tabular}

Source: Primary data

Table1 : reveals the age profile of SHG beneficiaries. The majority of the members are of the age group between 20-29 40-49 in two taluks of Shimoga District. Middle aged and married members are more involved in SHG and IGAs. who has more responsibility towards their family. 
Table 2: Educational profiles of the beneficiaries:

\begin{tabular}{|l|c|c|c|c|}
\hline \multirow{2}{*}{ Education } & \multicolumn{2}{|c|}{ Shimoga } & \multicolumn{2}{c|}{ Bhadravathi } \\
\cline { 2 - 5 } & No & $\%$ & No & $\%$ \\
\hline a) Illiterate & 4 & 16 & 6 & 24 \\
\hline b) Primary & 3 & 12 & 7 & 28 \\
\hline c) Secondary & 10 & 40 & 7 & 28 \\
\hline d) High school & 5 & 20 & 4 & 16 \\
\hline e) PUC & 2 & 8 & 1 & 4 \\
\hline f) Graduates & 1 & 4 & 0 & 0 \\
\hline Total & $\mathbf{2 5}$ & $\mathbf{1 0 0}$ & $\mathbf{2 5}$ & $\mathbf{1 0 0}$ \\
\hline
\end{tabular}

Source: Primary data

Table 2 : reveals the educational backgrounds of the members of SHGs. Majority of the members are below secondary and illiterates. Majority of the people who have high school, PUC and degree level of education were able to get the job or go for self-employment. However, the people who were deprived of formal education or had little education found it difficult in getting a job or starting individual enterprise. Because, these group of vulnerable poor are unable to get any financial and technical support. Hence, this study found that the members who are joining to the SHGs that are formed by the NGO for the income generating activities are having no formal education (illiterates) or most of them are having up to secondary education. This reveals a very interesting phenomenon. The IGAs taken up by SHGs motivated by NGOs have helped at the most to the people with very poor educational background. It indicates the real spirit of economic empowerment through IGAs of SHGs by increasing income and standard of living.

Table 3: Occupational backgrounds of the beneficiaries:

\begin{tabular}{|l|c|c|c|c|}
\hline \multirow{2}{*}{ Occupation } & \multicolumn{2}{|c|}{ Shimoga } & \multicolumn{2}{c|}{ Bhadravathi } \\
\cline { 2 - 5 } & No & $\mathbf{\%}$ & No & \% \\
\hline a) Agriculture & 3 & 12 & 4 & 12 \\
\hline b) Coolie & 11 & 44 & 10 & 40 \\
\hline c) Tailoring & 1 & 4 & 1 & 4 \\
\hline d) Beedi & 1 & 4 & 3 & 12 \\
\hline e) Government & 0 & 0 & 0 & 0 \\
\hline f) Private & 4 & 16 & 1 & 4 \\
\hline g) Business & $\mathbf{1}$ & $\mathbf{4}$ & $\mathbf{0}$ & $\mathbf{0}$ \\
\hline h) House wife & $\mathbf{3}$ & $\mathbf{1 2}$ & $\mathbf{4}$ & $\mathbf{1 6}$ \\
\hline i) Dairying & $\mathbf{1}$ & $\mathbf{4}$ & $\mathbf{2}$ & $\mathbf{8}$ \\
\hline Total & $\mathbf{2 5}$ & $\mathbf{1 0 0}$ & $\mathbf{2 5}$ & $\mathbf{1 0 0}$ \\
\hline
\end{tabular}

Source: Primary data

In all the cases (table3), the income of SHG members was irregular and not enough to satisfy even their basic needs. These are the reasons, which made the respondents to shift their preference to SHG and start IGAs either individually or groups. Thus occupational background of the respondents clearly reveals that IGAs of SHGs have immensely helped the unemployed to earn their bread. Shift from hazardous job to healthy occupation, irregular and low income job to regular income generating job. This indicates qualitative improvement in the employment. Regular employment and enhanced income was made a reality to the rural poor with low economic and educational profile through IGAs of SHGs is initiated by the SKDRDP.

Table 4: Current income status of beneficiaries:

\begin{tabular}{|c|c|c|c|c|}
\hline \multirow{2}{*}{ Income } & \multicolumn{2}{|c|}{ Shimoga } & \multicolumn{2}{c|}{ Bhadravathi } \\
\cline { 2 - 5 } & No & $\%$ & No & $\%$ \\
\hline Below 10000 & 9 & 36 & 6 & 16 \\
\hline $10001-14000$ & 6 & 24 & 4 & 32 \\
\hline $14001-20000$ & 3 & 12 & 7 & 28 \\
\hline Above 20000 & 7 & 28 & $\mathbf{2 5}$ & $\mathbf{1 0 0}$ \\
\hline Total & $\mathbf{2 5}$ & $\mathbf{1 0 0}$ & & \\
\hline
\end{tabular}


Table 5: Savings of SHG beneficiaries:

\begin{tabular}{|c|c|c|c|c|}
\hline \multirow{2}{*}{ Savings } & \multicolumn{2}{|c|}{ Shimoga } & \multicolumn{2}{c|}{ Bhadravathi } \\
\cline { 2 - 5 } Below 10000 & No & $\%$ & No & $\%$ \\
\hline $10001-30000$ & 15 & 60 & 6 & 24 \\
\hline $30001-50000$ & 5 & 20 & 7 & 28 \\
\hline Above 50000 & 4 & 16 & 8 & 16 \\
\hline Total & 1 & 4 & 4 & $\mathbf{1 0 0}$ \\
\hline
\end{tabular}

Source: Primary data

The table $4 \& 5$ depict the income and savings habit beneficiaries. Respondents clearly indicated that their income level and savings has increased after joining SHG and engaged in IGAs. They moved from the status of irregular income to regular income and from low income to high income. This speaks of the quality of improvement in the income level as well as standard of living of the respondents after joining SHGs and initiating IGAs. This also reveals the positive impact of IGA initiation in alleviating rural poverty and enhancing the standard of living as well as quality of the life of the people.

Table 6: Economic activities of SHG beneficiaries:

\begin{tabular}{|l|c|c|c|c|}
\hline \multirow{2}{*}{ Activities } & \multicolumn{2}{|c|}{ Shimoga } & \multicolumn{2}{c|}{ Bhadravathi } \\
\cline { 2 - 5 } & No & $\%$ & No & 8.3 \\
\hline a).Carpentry & 0 & 0 & 1 & 16.7 \\
\hline b) Tailoring & 1 & 10 & 2 & 8.3 \\
\hline c) Pottery & 1 & 10 & 1 & 8.3 \\
\hline d) Readymade garments & 0 & 0 & 0 & 0 \\
\hline e) Domestic products & 0 & 0 & $\mathbf{0}$ & $\mathbf{0}$ \\
\hline f) Cement dealing & $\mathbf{0}$ & $\mathbf{0}$ & 2 & 16.7 \\
\hline g) Dairying & 0 & 0 & 1 & 8.3 \\
\hline h) business & 1 & 10 & 2 & 16.7 \\
\hline i) Agriculture/fertilizers & 3 & 30 & $\mathbf{3}$ & $\mathbf{2 5 . 0}$ \\
\hline j) Cottage industries & $\mathbf{3}$ & $\mathbf{3 0}$ & $\mathbf{0}$ & $\mathbf{0}$ \\
\hline k) Dairy \&Poultry --- & $\mathbf{1 0}$ & $\mathbf{1 0 0}$ & $\mathbf{1 2}$ & $\mathbf{1 0 0}$ \\
\hline Total & & & & \\
\hline
\end{tabular}

Source: Primary data

Table 6 explains the different economic activities (IGAs) of SHG members in two taluks of Shimoga. In Shimoga taluk majority of the members taken up Agriculture/fertilizers and Cottage industries as their IGA(30\% and $30 \%$ respectively). In Bhadravathi taluk majority of the SHG members took dairying and Cottage industries as their IGA (constitute $16.57 \%$ and $25 \%$ ).

\section{Conclusion}

The initiatives of the Social entrepreneurs aim at generating employment opportunities and alleviating poverty by harnessing the available resources. In 1999 GOI merged all the anti poverty programmes into SGSY to promote self employment among men and women by training groups among them and enabling them to cross the poverty line. SKDRDP has contributed to the socio economic development of the poor and marginalized sections of the society. IGA particularly Group Enterprises setup by SHGs guided and supported by the NGOs (social enterprises), and Government has made remarkable progress. It has imbibed entrepreneurial talent among the people with a very low economic, social and educational background even in the remote area. Concepts of SHGs and IGAs have inculcated a very progressive expenditure pattern among the rural poor. Proactive role of the NGO has made the concept of Group enterprise a reality and developmental. Constitutional support is necessary in the initial days to motivate, strengthen and sustain IGAs by SHGs. SKDRDP model of empowering the poor through a government programme of SGSY is a successful model which can be replicated to spread and strengthen the rural empowerment initiatives. 


\section{References:}

[1]. Bogaert M.V., Das SP, Group Entrepreneurship with Rural poor; Indian social institute, New Delhi, 1989.

[2]. Chitvan Trivedi, social entrepreneurship bibliography, journal of entrepreneurship ,vol 19, No1, June 2010 pp 81-85

[3]. Dadhie C.L. (2001), "Micro finance - a panacea for poverty alleviation - A case study of oriental Grameena Project in India.

[4]. Dodkey MD, "SHGs and micro credit sustaining Rural Women", Social Welfare, March 1999.

[5]. Gangaiah, B. Nagaraja, C. Vasudevulu: "Impact of SHG on Income and

[6]. Marvin meadows, Mathew pike, Performance management of social

Employment", Kurukshethra, March 2006. 18-23

Vol.23, No2, and April 2010 pp 127-141

[7]. Pushazhandhi, Sathyasai (2000) Economic and Social empowerment of Rural poor through SHGs.

[8]. Ramachandran.T and A. Seilan "Socio economic empowerment and SHGs", Social welfare, , September 2005, Vol 52.( 3 to 7)

[9]. Rao V.M., Empowering Rural women, Anmol publications Pvt Ltd., New Delhi

[10]. Rory Ridly, Dutt, Social enterprise as a socially rational business, international journal of entrepreneurial behavior and research Vol.14, No 5, august 2005 pp 291-312

[11]. Senha Archana 2004, Micro finance for Women Empowerment, Kurukshethra, April. Vol.51

[12]. Sabyasachi Das ,SHGs and micro credit synergic integration (25-30) Kurukshethra, August 2003, , Vol. 51

[13]. Shyklendra H.S. (1998), Promoting women SHGs: Lessons from action research project of IRMA: Gujarat

[14]. SKDRDP study report 2012-13. 